\title{
Mapping of Soil Erosion Hazard Zones of Sri Lanka
}

\author{
M.J.P.T.M. Jayasekara*, H.K. Kadupitiya ${ }^{1}$ and U.W.A. Vitharana ${ }^{2}$
}

Postgraduates Institute of Agriculture

University of Peradeniya

Peradeniya

\begin{abstract}
Soil erosion is a dynamic process where productive topsoil is removed causing loss of land productivity and reduction in storage capacity of surface water bodies. Soil erosion is one of the major causes of land degradation in most areas of Sri Lanka. Therefore, the assessment of erosion hazard of different areas of Sri Lanka is a necessity to apply appropriate conservation measures and combat the land degradation. This study focused on mapping of erosion hazard zones by combining Geographic Information System (GIS) data along with In VEST model. Soil erosion hazard zone maps were developed for each district and for whole Sri Lanka. Results showed that $11.8 \%$ of the area in Sri Lanka is under high hazard level of erosion and $4.8 \%$ of the area is under very high level of hazard which are intolerable for any land use with respect to the sustainable productivity. Furthermore, six districts namely Badulla (36.5\% high erosion hazard), Kandy (32\%), Kegalle (38.5\%), Nuwara Eliya (40.7\%), Rathnapura (38.7\%) and Matale (20.3\%) showed considerable susceptibility for soil erosion mainly due to the topography and the land use. Four other districts namely, Galle (20\% high erosion hazard), Matara (20\%), Kaluthara (20\%) and Colombo (9\%) also showed high tendency for soil erosion due to the land use changes with the urbanization. These areas should be given priority when implementing soil conservation practices and land use changes to reduce further soil loss.
\end{abstract}

Keywords: Erosion hazard zones, geographic information system, In VEST model, soil erosion

\section{INTRODUCTION}

Soil erosion is one of the most contributing processes of land degradation in Sri Lanka affecting the national food production as well as natural ecosystems. Soil erosion removes surface soil rich in nutrients causing negative feedbacks on availability and productivity of agricultural lands as well as the water storage capacity of reservoirs. Although soil erosion is a naturally occurring process, this has been accelerated by human activities such as intensive agriculture, improper land management, deforestation and cultivation on steep slopes.

In Sri Lanka, many studies have been conducted to assess soil erosion based on both numerical modeling and actual quantification and shown that soil erosion is a severe problem in Sri Lanka (Wickramasinghe, 1988; Nayakakorale, 1998; Wijesekara and Chandrasena, 2001; Wijesekara and Samarakoon, 2001; Abeysinghe et al., 2005; Jayarathne et al., 2010). Soil erosion is occurring at an alarming rate not only in central highland but also in lowlands due to changes in land use, removal of vegetative cover and urbanization. Therefore,

\footnotetext{
1 Natural Resource Management Centre, Department of Agriculture, Preadeniya, Sri Lanka

Department of Soil Science, Faculty of Agriculture, University of Peradeniya, Sri Lanka

* Corresponding author: thinimadhu@gmail.com
} 
assessment of erosion hazard of different areas of Sri Lanka is a necessity to apply appropriate conservation measures and combat land degradation. However, risk assessment of soil erosion is a challenging task due to complexity of factors determining soil erosion (Alkharabsheh et al., 2013). Developments of Geographic Information System (GIS) and availability of information layers addressing environmental controllers of soil erosion have opened up new possibilities to model soil erosion. Mapping of erosion hazard zones using GIS has been conducted in many countries (Kothyari and Jain, 1997; Priya and Shibasaki, 1998) including Sri Lanka using universal soil loss equation (USLE) in GIS (Brieby, 2001). However, Borselli (2008) showed that USLE predictions can produce over estimates of sediment loss due to non-consideration of the quantity of eroded soil actually reaching the catchment outlet. Thus, integration of USLE predictions with sediment delivery ratio (SDR) at pixel level can make more realistic estimates. InVEST (Integrated Valuation of Environmental Services and Tradeoffs) Sediment Delivery Ratio model (Sharp et al., 2015) is a biophysical model that is capable of applying the findings of Borselli (2008) for more accurate estimation of soil erosion and which has been extensively used in many countries (Bahattarai and Dutta, 2006; Cavalli et al., 2013). This model calculates the amount of eroded sediment for each cell first using the Revised Universal Soil Loss Equation (RUSLE) and then the sediment delivery ratio which is the proportion of soil loss actually reaches to the catchment. However, this new model has not still been used in Sri Lanka to assess soil erosion. Therefore, this study was conducted to construct the map of soil erosion hazard zones of Sri Lanka using InVEST sediment delivery ratio model.

\section{Study area}

\section{METHODOLOGY}

To cover entire Sri Lanka $\left(65,610 \mathrm{~km}^{2}\right)$, erosion hazard mapping was done at country and district levels (Figure 1).

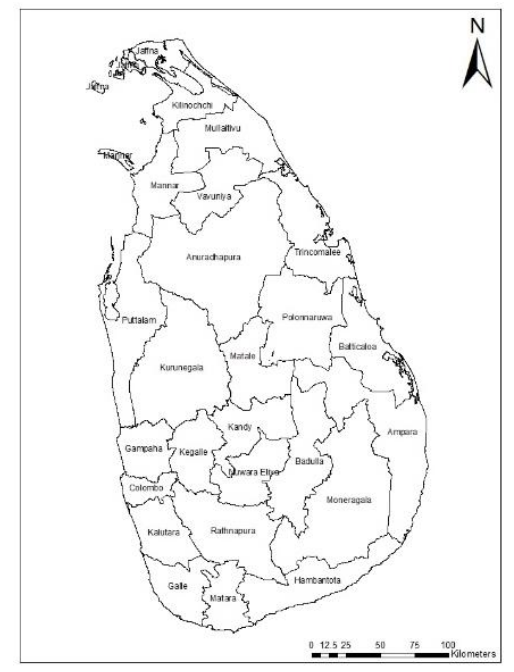

Figure 1. Map of Sri Lanka showing district boundaries

Seven layers of information (Table 1) were used in this study to prepare model inputs for the InVEST model. All thematic layers were transformed to a compatible format by projecting to 
UTM projection system of raster format in WGS 84 datum. GIS software, ArcMap 10.2.2 was used for spatial analysis and storage of model inputs.

Table 1. Data used for InVEST sediment delivery ratio model and their sources

\begin{tabular}{ll}
\hline Data & Sources \\
\hline Digital Elevation & SRTM satellite images \\
Rainfall & Department of Meteorology \\
Soils of Sri Lanka & De Alwis and Panabokke (1972) \\
Land Use Land Cover & Land Use map (1:50 000) from LADA project \\
Watershed & River basin map-Department of Irrigation \\
C and P factor & Kuok et al., 2013 \\
\hline
\end{tabular}

\section{Digital Elevation Model (DEM)}

Digital Elevation Model is a spatial data layer that stores the elevation of a land area. This raster model provides necessary information to calculate sediment transport at pixels basis. The DEM of Sri Lanka was generated using Shuttle Radar Topography Mission (SRTM) satellite images (30 $\mathrm{m}$ resolution).

\section{Rainfall Erosivity (R) Factor}

Rainfall erosivity is the power of rainfall to cause erosion and it depends on the amount of rainfall and its intensity. Rainfall erosivity factor for each cell was determined from the average annual rainfall data (2006-2016). Thus, the regression model of Wickramasinghe and Premalal, (1989) was used:

$$
\mathrm{R}=\frac{(972.75+9.95 \mathrm{x} \text { Mean Annual Rainfall })}{100}
$$

\section{Soil Erodibility (K) Factor}

Soil erodibility factor quantifies the susceptibility of soil particles to detach by rainfall and transported by runoff (Wischmeier and Smith, 1978). Thus, raster geo information layer (30 $\mathrm{m}$ resolution) of K was prepared. Joshua, (1997) calculated K values for major great soil groups and for rock knob planes and erosional remnants (Table 2). Using this information, digitized soil map of Sri Lanka (Alwis and Panabokke, 1972) was transformed to the map of $\mathrm{K}$ as an input for InVEST model.

Table 2. Soil erodibility factor values of great soil groups of Sri Lanka

\begin{tabular}{ll}
\hline Soil type & Value \\
\hline Reddish Brown Earth & 0.27 \\
Low Humic Glay & 0.27 \\
Erosional Remnants (Inselbergs) & 0.10 \\
Rock Knob Plains & 0.10 \\
Alluvial & 0.15 \\
Red Yellow Podzolic & 0.22 \\
Red Yellow Latasols & 0.33 \\
Non- Calcic Brown & 0.35 \\
Soladized solanets & 0.4
\end{tabular}




\section{Land Use Land Cover (LULC) and watersheds}

The land use land cover layer generated by the national level report of Land Degradation Assessment in Dry lands (LADA report, 2013) was used. The raster geo information layer of LULC was generated by rasterizing process. The erosion modeling was performed at watershed level. Therefore, the river basin map of Sri Lanka was used to generate the map of major watersheds in Sri Lanka.

\section{Crop (C) and Management (P) factors}

Crop factor is the ratio of soil loss under a given crop to that of bare soil. It indicates the effect of plants, soil cover and soil disturbed activities on soil loss. The $\mathrm{C}$ factor of land depends on the crop type and tillage practices used. Crop factor values pertaining to land use and land cover types of Sri Lanka were obtained from literature (Kuok et al., 2013) (Table 3) and these data have been applied for Sri Lanka in previous erosion studies (Udayakumara and Gunawardena, 2016).

The $\mathrm{P}$ factor accounts for the effect of management practices on the amount and rate of runoff and hence the soil erosion and $\mathrm{P}$ factor depends on support practice methods (Stone and Hilborn, 2000). Values for the $\mathrm{P}$ factor were also obtained from existing literature (Kuok et al., 2013) (Table 3). These P factor data has also been applied in previous studies in Sri Lanka (Thuraisingham and Weerasinghe 2009; Udayakumara and Gunawardena, 2016).

Table 3. C factor and $P$ factor value for each land use type

\begin{tabular}{|c|c|c|}
\hline Land use type & C factor & P factor \\
\hline Water Features & 0.001 & 0.001 \\
\hline Forest & 0.001 & 0.1 \\
\hline Rocks & 0.0001 & 0.001 \\
\hline Paddy & 0.2 & 0.15 \\
\hline Tea & 0.2 & 0.5 \\
\hline Grassland & 0.01 & 0.2 \\
\hline Crop & 0.1 & 0.25 \\
\hline
\end{tabular}

Sources: Kuok et al., 2013

\section{Assessing soil erosion using InVEST}

In this study, InVEST sediment delivery ratio (SDR) model was used to map and assess soil erosion (Sharp et al., 2015). InVEST was developed as a part of Natural Capital project with the collaboration of Stanford University, World Wildlife Fund (WWF), the Nature Conservancy and many other institutions (Nelson et al., 2009).

When assessing soil erosion using this model, InVEST sediment delivery ratio model uses the Universal Soil Loss Equation (USLE) (Wischmeier and Smith 1978), at the pixel scale to identify potential soil loss and amount of sediment delivered to the stream. It combines information on Land Use Land Cover (LULC) patterns and soil properties (texture, structure, organic matter content etc.), as well as a digital elevation model (DEM), climate and rainfall data to predict changes in erosion. For each cell, the model calculates the amount of sediment eroded and then the sediment delivery ratio which is the proportion of soil loss actually reaching the catchment exit. The output from this model comprise the sediment load delivered to the stream and amount of sediment eroded in the catchment at an annual scale. 


\section{Preparation of soil erosion hazard Map}

All maps layers were used as input data for InVEST model to run the model and generate soil erosion hazard map of Sri Lanka. Furthermore, soil erosion hazard maps for each district were constructed separately.

\section{RESULTS AND DISCUSSION}

\section{Spatial distribution of input data of InVEST model}

Digital elevation model, rainfall erosivity, soil erodibility, land use and river basin geo information layers are presented in Figure 2. The elevation is distributed from sea level to $2500 \mathrm{~m}$ and the digital elevation model clearly demarcates three elevation zones, central highlands, plains and the coastal belt. The erosivity factor ranges from 100 to 500. High values of $\mathrm{R}$ were observed in Western and central highlands of Sri Lanka those receive majority of rainfall from the southwest monsoon.
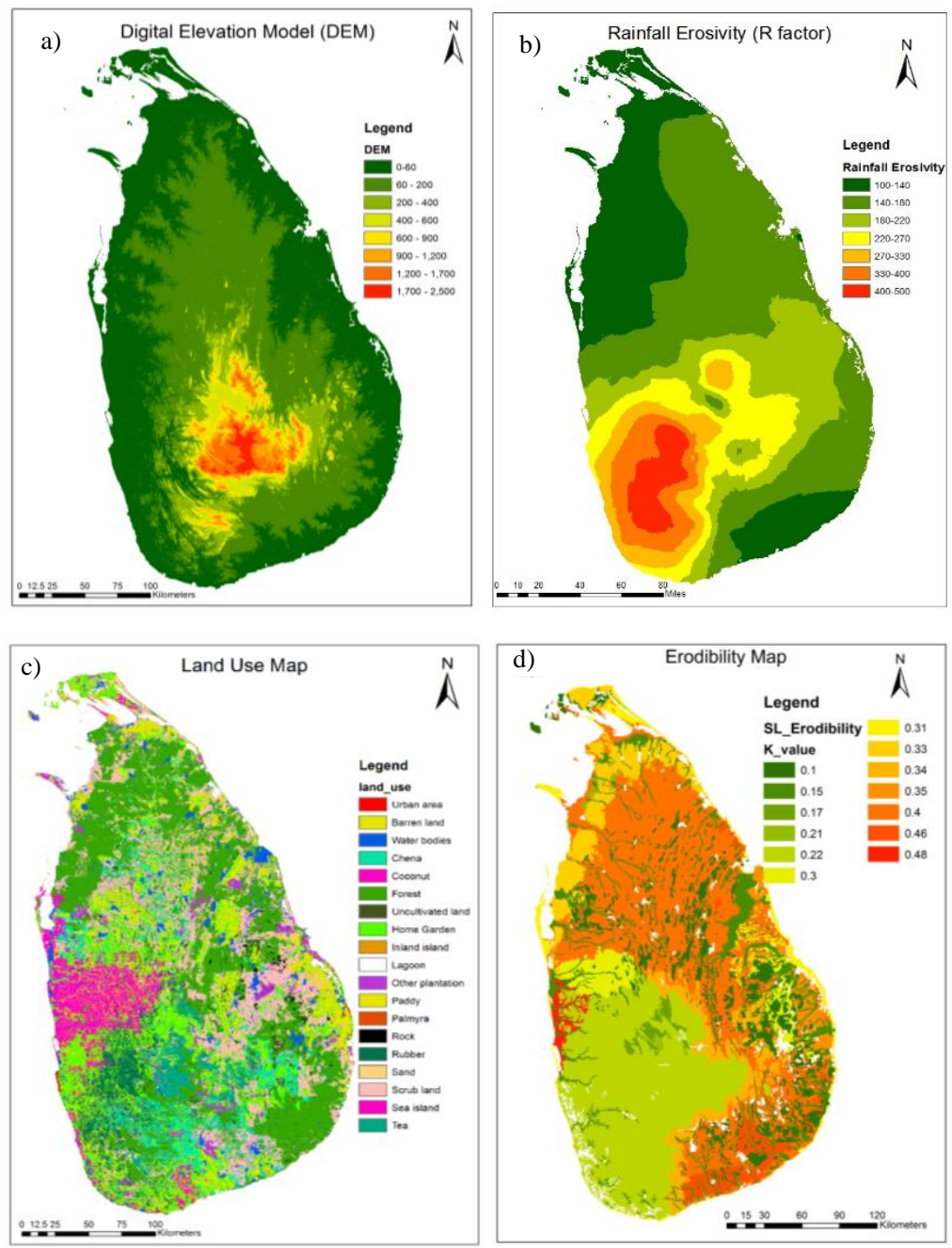


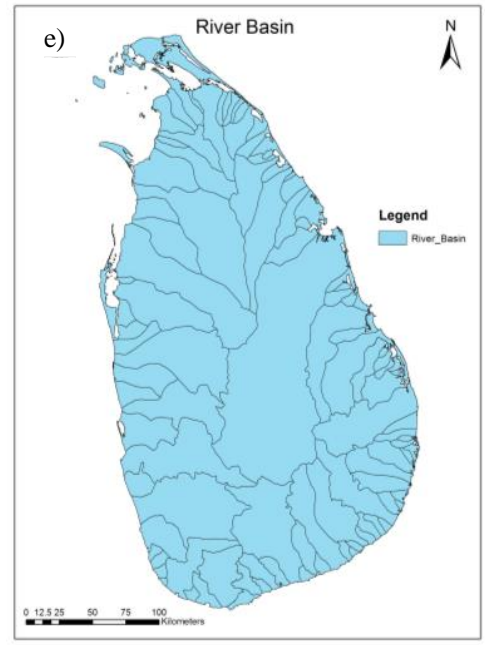

Figure 2. Input spatial data layers of InVEST a) Digital Elevation Model, b) Rainfall Erosivity (R) factor, c) Soil Erodibility (K) factor, d) River basin and e) Land Use Land Cover (LULC) map.

Soil erodibility factor depicts the susceptibility or resistance of soils to erosion. Higher values of $\mathrm{K}$ factor show areas those susceptible for water erosion. Such soils are inherently low in aggregate stability. According to Joshua (1997), the relative susceptibility of different great soil groups of Sri Lanka follows the order of non calcic brown > red yellow latosol > reddish brown earth> red yellow podzolic soils> reddish brown latosolic soils. Spatial distribution map of $\mathrm{K}$ factor indicates that the soils of large part of the dry zone are susceptible for erosion. Red yellow podzolic soil, the dominant wet zone soil, is more resistant for erosion.

Land use cover is one of the factors in determining the degree of soil erosion. In this study, nineteen major land use cover (LULC) classes (Figure 2d) were identified. About $26 \%$ of land is covered by forest, $14 \%$ accounts for home garden, $13 \%$ accounts for paddy lands and $16 \%$ is covered by scrub lands.

\section{Soil erosion hazard assessment}

InVEST model resulted the map of average annual soil loss. This map was classified into five levels of soil erosion hazard (Table 4) according to Senanayake et al. (2013).

Table 4. Erosion hazard levels (Senanayake et al., 2013)

\begin{tabular}{lc}
\hline Erosion hazard level & Average annual soil loss $(\mathbf{t} / \mathbf{h a} / \mathbf{y r})$ \\
\hline Low & $0-5$ \\
Moderate & $5-12$ \\
High & $12-25$ \\
Very high & $25-60$ \\
Extremely high & $>60$ \\
\hline
\end{tabular}

The resultant soil erosion hazard map for Sri Lanka is given in Figure 3. Although higher soil erodibility was observed in the dry zone (Figure 2c), lower hazard of soil erosion was 
resulted due to less contribution from flat and gently undulating terrain on the rate of soil erosion. Higher soil erosion hazard was observed in up country due to greater contribution of rainfall erosivity and hilly to mountainous topography.

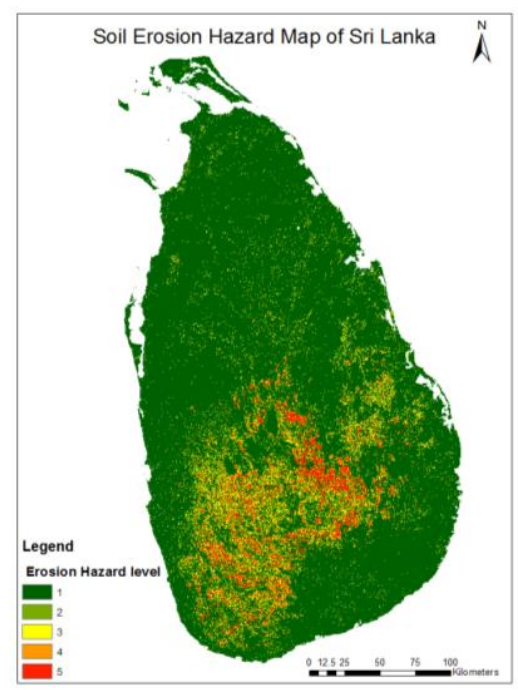

Figure 3. Soil erosion hazard map of Sri Lanka (1=low, $2=$ moderate, $3=$ high, $4=$ =very high and 5=extremely high)

Senanayake (2013) stated that areas of both low and moderate levels of soil erosion hazard can be allowed for agriculture. Areas under high, very high and extremely high levels should however be managed for crop cultivation with utmost care to avoid the degradation of lands. Thus, this study revealed that $83.5 \%$ of the area of Sri Lanka is under low hazard of soil erosion and $4.8 \%$ is under moderate hazard level. Moreover, the percentage of area under high level of hazard is $11.8 \%$ which is intolerable for any land use with respect to the sustainable productivity. Implementation of proper soil conservation practices are of utmost importance to arrest the severe erosion presently occurring in these areas.

\section{Soil erosion hazard assessment of different districts}

According to district level maps of soil erosion hazard, six districts, Badulla, Kandy, Kegalle, Nuwara eliya, Rathnapura and Matale were identified as districts that are susceptible for severe erosion. 

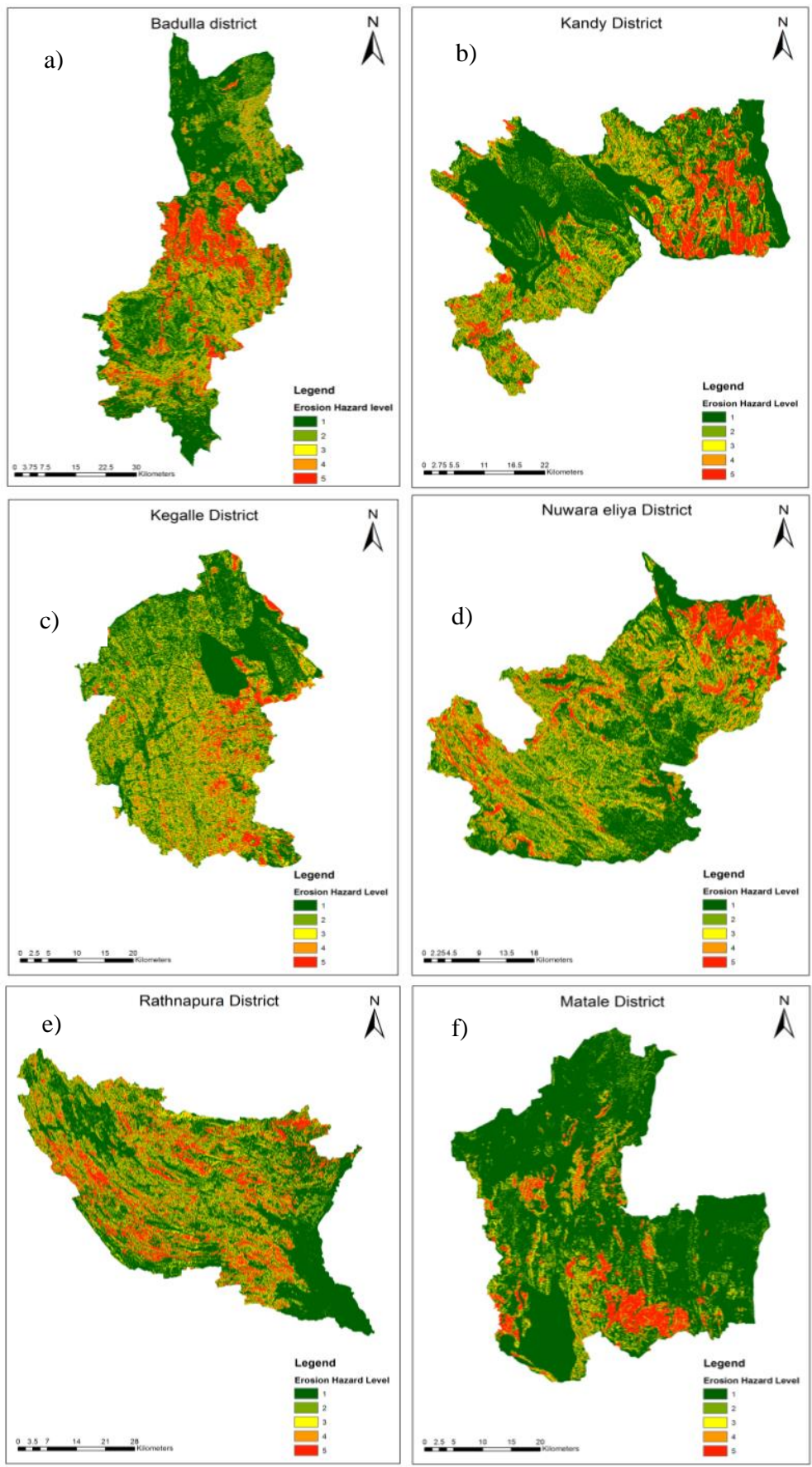

Figure 4. Erosion hazard maps of a) Badulla district, b) Kandy district, c) Kegalle district, d) Nuwara Eliya district, e) Rathnapura district and f) Matale district (1=low, 2=moderate, $3=$ high, $4=$ =ery high and $5=$ =xtremely high)

In Badulla district, 36.5\% area out of total area is under high to extremely high erosion hazard level. Moreover, 32\% in Kandy district, 38.5\% in Kegalle district, $40.7 \%$ in Nuwara 
Eliya, 38.7\% in Rathnapura and 20.3\% in Matale district are under high to extremely high erosion hazard level (Figure 4).

Factors such as climate (high rainfall intensity), and topography (slope) are reasons for severe erosion in these districts despite of low erodibility of the dominant great soil group, red yellow podzoilic soil. All these districts receive more than $2500 \mathrm{~mm}$ annual rainfall and slope percentage is more than $20 \%$.

In addition to these natural factors, human induced factors can also be attributed for severe erosion in these districts. Hammen et al. (2015) showed that the land use changes from forests to cultivated lands directly effect on elevated level of soil erosion. Tea cultivation is one of the major land uses in Badulla (20\%), Kandy (23\%) and Nuwara Eliya (43\%) districts. Majority of Kegalle (44\%) and Rathnapura districts (16\%) are occupied with rubber plantations. In Rathnapura district, Chena cultivation is frequently practiced (26\% of total land). Generally, soil erosion is considered to be more severe in plantations in these areas because of cultivation on steep slope and poor crop and land management practices under plantations and other agricultural lands (Senanayake et al., 2013).

These districts are major contributors for supplying vegetables for local consumers and earning foreign revenue from tea and rubber. Severe erosion in these districts can have a significant impact on the economy of Sri Lanka by lowering the land productivity and potential cultivable areas in long term. Therefore, implementation of proper soil conservation practices and monitoring of soil erosion are essential in order to reduce further soil loss.

High erosion hazard was observed in other districts such as Galle, Matara, Kaluthara and Colombo and they are located in the low country wet zone (Figure 5). Among these districts, $20 \%$ of the area of Galle, Kaluthara and Matara districts are at high to extremely high levels of erosion hazard. Moreover, $9 \%$ of the land area of Colombo district is in high to extremely high level of soil erosion hazard.
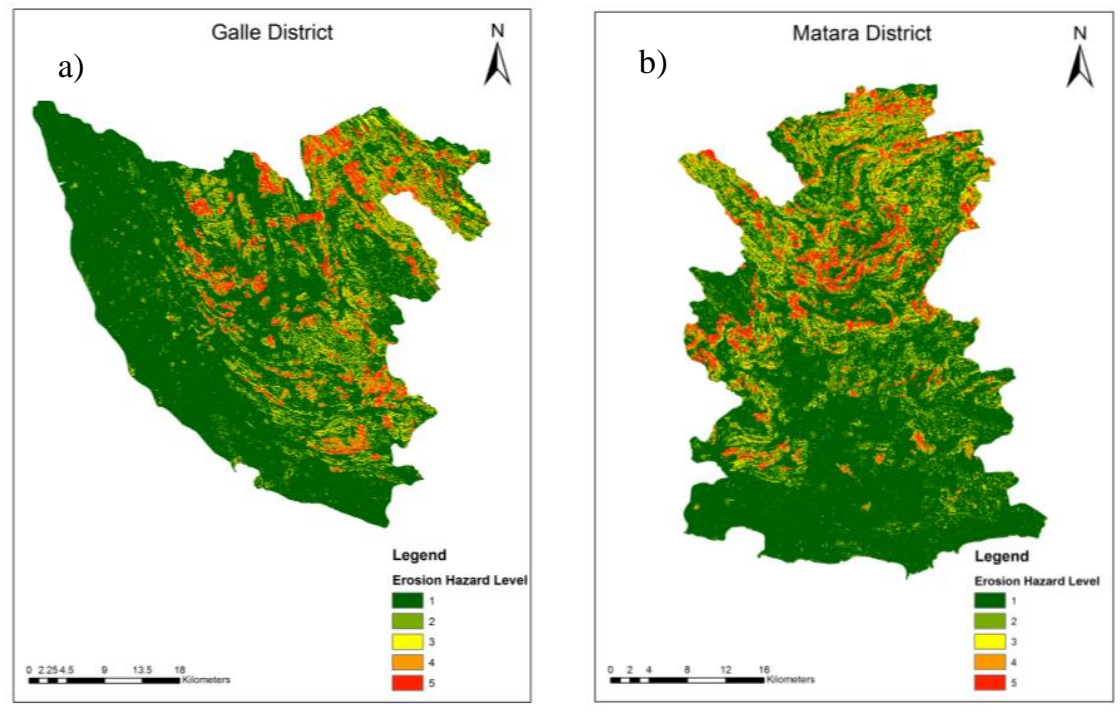

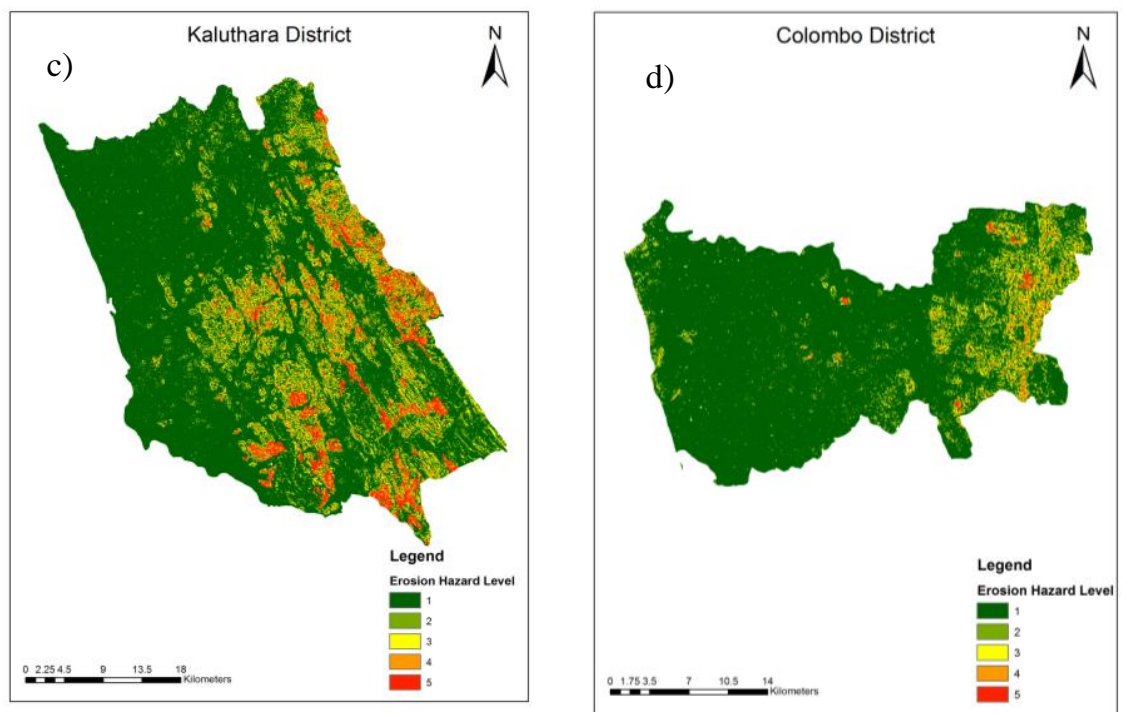

Figure 5. Erosion hazard maps of a) Galle district, b) Matara district, c) Kaluthara district and d) Colombo district (1=low, 2=moderate, 3=high, 4=very high and $5=$ extremely high)

When land use changes, deforestation could also be stated as possible reasons for severe erosion in these districts. In Galle district more than $30 \%$ of land has been changed to cultivated lands and this change was $42 \%$ in Matara district, $38 \%$ in Kaluthara district and $40 \%$ in Colombo district.

According to LULC map (Figure 2), urbanization can also be a reason for severe erosion in these districts. With rapid development of economy of the country, more buildings, highways, and roads were constructed within last decades and this accelerated urbanization could lead to severe erosion in these districts. Hu et al., (2001) observed that urbanization as one of the major cause of soil erosion that lead to reduction water storage capacity, high rates of runoff, and resulting frequent flash floods in urban areas. Therefore, impacts of urbanization on erosion should also be taken into consideration when planning to exploit natural resources or to develop urban areas in these districts.

\section{CONCLUSIONS}

This study revealed that assessment and mapping of soil erosion hazard using GIS techniques along with InVEST model provides great advantage when generating spatial information on erosive factors and estimate soil loss rates over large areas. Lands in many districts in Sri Lanka are subjected to severe erosion that is intolerable for any land use with respect to the sustainable productivity. These areas need urgent attention to reduce further soil loss. Moreover, conservation practices should be implemented in areas under low erosion hazard levels as well, since the cost of practice is more affordable and applicable at the early stages. Furthermore, it is suggested to conduct soil erosion studies at field level to validate model predictions. 


\section{REFERENCES}

Abeysinghe, A., Iwao, Y., Saito, A. and Bandara, R. (2005). Hazard and Risk Assessment in Landslide Prone Hill Country of Sri Lanka. Geotech. J. 3(1), 3-4. Retrieved August 15, 2016.

Alkharabsheh, M., Alexandridis, T., Bilas, G., Misopolinos, N. and Silleos, N. (2013). Impact of land cover change on soil erosion hazard in northern Jordan using remote sensing and GIS. Procedia Env. Sci. 19, 913.

Bai,Y., Zhuang, C., Ouyang, Z., Zheng, H. and Jiang, B. (2011). Spatial characteristics between biodiversity and ecosystem services in a human-dominated watershed. Ecol. Complex. 8, 177-183.

Bhattarai, R. and Dutta, D. (2006). Estimation of soil erosion and sediment yield using GIS at catchment scale. Water Resour. Manag. 21, 1635-1647.

Borselli, L., Cassi, P. and Torri, D. (2008). Prolegomena to sediment and flow connectivity in the landscape: A GIS and field numerical assessment. Catena 75, 268-277

Breiby, T. (2001). Assessment of Soil Erosion Risk within a Sub Watershed using GIS and RUSLE with a Comparative Analysis of the use of STATSGO and SSURGO Soil Databases. Department of Resource Analysis, Saint Mary's University of Minnesota, Winona, USA.

Cavalli, M., Trevisani, S., Comiti, F. and Marchi, L. (2013). Geomorphometric assessment of spatial sediment connectivity in small Alpine catchments. Geomorph. 188, 31-41.

De Alwis, K.A., and Panabokke, C.R. (1972). J. Soil Sci. Soc. Sri Lanka, 2, 1-9.

Hamman, K.B., Issa, L.K. and Rachid, M. (2015). Effect of vegetation cover and land use changes on soil erosion in Kalaya watershed. Int.J. Geo. Sci. 6,1353-1366.

Jayarathne, K.D.B.L., Dayawansa, N.D.K. and De Silva, R.P. (2010). GIS based analysis of biophysical and socio economic factors on land degredation in Kandaketiya DS division. Trop. Agri. Res. 21, 361-367.

Joshua, W.D.(1977). Soil erosive power of rainfall in the different climatic zones of Sri Lanka [Online] Available from https://www.itia.ntua.gr/hsj/redbooks/122/iahs_122_0051.pdf

Kothyari, U.C. and Jain, S.K. (1997). Sediment yield estimation using GIS. Hydrolog. Sci. J. 42, 833-843.

Kuok, K.K., Mah, D.Y. and Chiu, P. (2013). Evaluation of C and P factors in universal soil loss equation on trapping sediment: case study of Santubong River. J. Water Res. Pro. 5, 1149.

Nayakekorala, H.B. (1998). Human Induced soil degradation status in Sri Lanka. J. Soil Sci. Soc. Sri Lanka. 10, 1-35.

Nelson, E., Mendoza, G., Regetz, J., Polasky, S., Tallis, H., Cameron, D., Chan, K.M., Daily, G.C., Goldstein, J. and Kareiva, P.M. (2009). Modeling multiple ecosystem services, 
biodiversity conservation, commodity production, and tradeoffs at landscape scales. Front. Ecol. Environ. 7, 4-11.

Priya, S. and Shibasaki, R. (1998). Quantification of soil loss and its prediction using GIS and Remote Sensing Technology. Asian Pac. Remote Sens. GIS J.10, 15-27.

Sharp, R., Tallis, H.T., Ricketts, T., Guerry, A.D., Wood, S.A., Nelson, E., Ennaanay, D., Wolny, S., Olwero, N., Vigerstol, K., Pennington, D., Mendoza, G., Aukema, J., Foster, J., Forrest, J., Cameron, D., Arkema, K., Lonsdorf, E., Kennedy, C., Verutes, G., Kim, C.K., Guannel, G., Papenfus, M., Toft, J., Marsik, M., Bernhardt, J., Griffin, R., Glowinski, K., Chaumont, N., Perelman, A., Lacayo, M., Mandle, L., Hamel, P. and Chaplin-Kramer, R., (2015). InVEST 3.0 User's Guide. The Natural Capital Project. Stanford, California, USA.

Senanayake, S.S., Munasinghe M.A K. and Wickremasinghe, W.M.A.D.B. (2013). Use of erosion hazard assessments for regional scale crop suitability mapping in the Uva province. Ann. Sri Lanka Depart. Agric. p.133-147.

Stone, R.P. and Hilborn, D. (2000). Universal Soil Loss Equation, USLE, Fact Sheets 12051, Ministry of Agriculture, Food and Rural Affairs, Ontario, Canada.

Hu, S., Zhi-mao, G. and Jun-ping, Y. (2001). The impacts of urbanization on soil erosion in the Loess Plateau region: J. Geogr. Sci. 11, 282-290. https://doi.org/10.1007/BF02892311

Thuraisingham, K. and Weerasinghe, V.P.N. (2009). Soil erosion study for Bibili Oya watershed in Kelani river basin [on line]. [Accessed on 08.05.2017]. Available at https://www.researchgate.net/...erosion.../Soil-erosion-study-for-Bibili-Oya

Udayakumara, E.P.N. and Gunawardena, U.A.D.P. (2016). Reducing siltation and increasing hydropower generation from the Rantambe reservoir, Sri Lanka. South Asian Network for Development and Environmental Economics (SANDEE). pp.13-26.

Wickramasinghe L.A. and Premalal W.P.R. (1989). Development of a Rain Erosivity Map for Sri Lanka. Proceedings of the Fifth International Conference on Soil Conservation for Future Generations, Bangkok, Thailand, November, 1989. pp. 441-450. https://www.researchgate.net/...Premalal...DEVELOPMENT_OF_A_RAINSTORM_EROSI $\mathrm{ON}$

Wickramasinghe, A. (1988). Impact of Land Use Practices on Environment Conditions of the Hill Country of Sri Lanka. J. Soil Sci. Soc. Sri Lanka. 3, 10-25.

Wijesekara, N.T.S. and Chandrasena, K.G. (2001). Calibration of a GIS based watershed model to identify priority zones for soil conservation. Proceeding of the Asia GIS 2001 Symposium, Tokyo.

Wijesekera, S. and Samarakoon. L. (2001). Extraction of parameters and modeling soil erosion using GIS in a GRID environment. Proccedings of the $22^{\text {nd }}$ Asian Conference on Remote Sensing. Singapore, November, 2001.

Wischmeier, W., and Smith, D. (1978). Predicting Rainfall Erosion Losses; A Guide to Conservaton Planning (Agricultural handbook No. 537). Washington DC, USA: US Department of Agriculture Science and Education Administration. 